\title{
Inhibitory effect of $\beta$-pinene, $\alpha$-pinene and eugenol on the growth of potential infectious endocarditis causing Gram-positive bacteria
}

\author{
Aristides Medeiros Leite', Edeltrudes de Oliveira Lima² ${ }^{2}$ Evandro Leite de Souza ${ }^{3}$, Margareth de \\ Fátima Formiga Melo Diniz'1 , Vinícius Nogueira Trajano², Isac Almeida de Medeiros ${ }^{1}$
}

'Laboratório de Tecnologia Farmacêutica, Universidade Federal da Paraíba, João Pessoa, ${ }^{2}$ Laboratório de Micologia, Departamento de Ciências Farmacêuticas, Centro de Ciências da Saúde, Universidade Federal da Paraíba, João Pessoa, ${ }^{3}$ Departamento de Nutrição, Centro de Ciências da Saúde, Universidade Federal da Paraíba,

João Pessoa

*Correspondence:

E.L. Souza

Rua Radialista Antônio Assunção de Jesus, 680/102,

58052-230 - João Pessoa - PB, Brasil

E-mail: evandroleitesouza@ccs.ufpb.br
This study was led with the purpose of evaluating the effectiveness of eugenol, $\beta$-pinene and $\alpha$-pinene in inhibiting the growth of potential infectious endocarditis causing gram-positive bacteria. The phytochemicals Minimum Inhibitory Concentration-MIC was determined by solid medium diffusion procedure, while the interference of the MIC values on the bacterial cell viability was performed by viable cells count. Staphylococcus aureus, S. epidermidis, Streptococcus pneumoniae and $\mathrm{S}$. pyogenes strains were used as test microorganisms. The assayed phytochemicals showed effectiveness in inhibiting all assayed bacteria strains presenting MIC values between 2.5 and $40 \mu \mathrm{L} / \mathrm{mL}$. Eugenol showed the lowest MIC values which were between 2.5 and $5 \mu \mathrm{L} / \mathrm{mL}$ for the most bacteria strains. MIC values found to the phytochemicals were able to inhibit the cell viability of $S$. aureus providing a total elimination of the bacteria inoculum in a maximum time of 24 hours of exposure. These data showed the interesting antibacterial property of the assayed phytochemicals and support their possible and rational use in the antimicrobial therapy.

\section{INTRODUCTION}

Infectious endocarditis (IE) is an infectious disease attacking mainly the heart valves endocardium. Most cases of IE has been related to infections caused by Streptococcus and Staphylococcus genus, although bacteria inserted in the HACEK group (Haemophillus parainfluenzae, $H$. aphrophilus, $H$. paraphrophilus, $H$.
Uniterms

- Endocarditis

- Gram positive bacteria

- Phytochemicals

- Antibacterial activity influenzae, Actinobacillus actinomycetemcomitans, Cardiobaccterium hominis, Eikenella corrodens, Kingela kingae and $K$. denitrificans) have presented an emerging importance as IE causing agents (Baddour et al., 2005; Bashore et al., 2006). Fungi can act as IE etiological agents in immunosuppressed people and/or in catheter and valve prosthesis users (Niwa et al., 2003; Watanabe et al., 2003; Anguera et al., 2005). 
Even regarding the advances in the clinical therapy the IE still presents a high mortality rate $(20 \%$ to $30 \%$ of the cases). It has been related to the development of antibiotic resistance by IE causing agents, mainly when regarded the Staphylococcus genus because the appearance of methicillinresistant Staphylococcus aureus (MRSA) (Nakatani et al., 2003; Ishiwada et al., 2005). Some researchers have reported that the rising of MRSA strains has been responsible for an increase in the action of Staphylococcus genus as IE causing agent. On the other hand, the participation of Streptococcus genus in IE etiology has decreased (Ako et al., 2003; Pigrau et al., 2005; Ferreiros et al., 2006).

Currently there has been an increasing interest in studying the biological properties of plant and derivatives in order to discover alternative biologically active compounds (Seidil, 2000; Araújo et al., 2004; Lima et al., 2005). Plant products have received a renewed interest in their use as alternative source of antimicrobial compounds because the uncontrolled use of the antimicrobial chemotherapy (Dorman, Deans, 2000). The successful history of microbial chemocontrol lies in the continuous rising of microbial strains with resistance to the classical antibiotics (Notermans, HoogenboonVerdegaal, 1992). Researches regarding the antimicrobial activity of phytochemicals have been yet little emphasized being the most studies addressed to evaluate the antimicrobial effect of essential oils and extracts (Nascimento et al., 2000; Souza et al., 2005).

This study aimed to evaluate the effectiveness of eugenol, $\beta$-pinene and $\alpha$-pinene in inhibiting the growth of Gram-positive bacteria known as potential IE etiological agents.

\section{MATERIAL AND METHODS}

\section{Phytochemicals}

Eugenol, $\alpha$-pinene and $\beta$-pinene were supplied by Department of Pharmaceutical Sciences, State University of Ponta Grossa, Paraná, Brazil. The phytochemicals were tested at concentrations ranging from 160 to $1.25 \mu \mathrm{L} / \mathrm{mL}$, and the solutions were prepared prior to the antimicrobial assays according to Souza et al. (2007). Molecular structures of the phytochemicals are shown in Figure 1.

\section{Bacteria strains}

Staphylococcus aureus ATCC 13150, S. aureus ATCC $6538, S$. aureus ATCC 25932, S. aureus ATCC LB 126, S. epidermidis SSI 1, S. epidermidis ATCC 12228, Streptococcus pyogenes ATCC 19615, Streptococcus

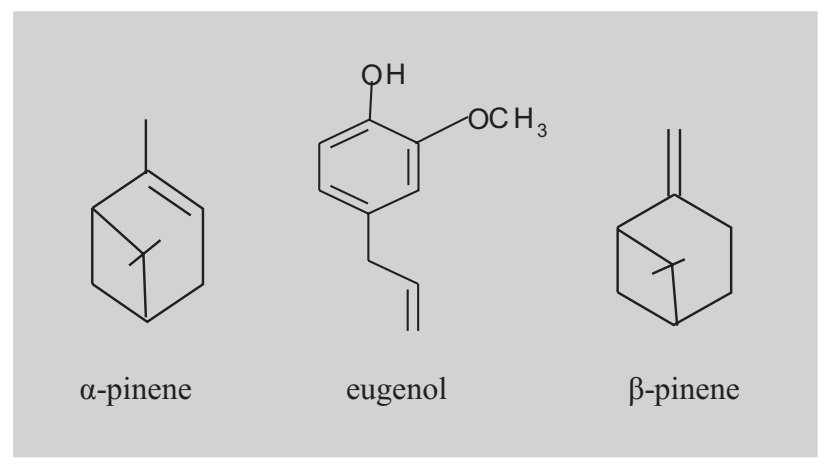

FIGURE 1 - Molecular structures of phytochemicals used in the antimicrobial assays.

pyogenes ATCC 8668 and S. pneumoniae ATCC 11773 were used as test microorganisms. These strains were supplied by Laboratory of Clinical Bacteriology, Department of Pharmaceutical Sciences, Health Sciences Center, Federal University of Paraíba, Brazil. Stock cultures were maintained on nutrient agar slants at $4{ }^{\circ} \mathrm{C}$. Inocula used in antimicrobial assays were obtained from overnight cultures grown on nutrient agar slants at $37^{\circ} \mathrm{C}$ and diluted in sterile saline solution $(0.85 \% \mathrm{w} / \mathrm{v})$ to have a final concentration of $10^{6}$ colony forming unity (cfu) $/ \mathrm{mL}$ (adjusted according to the turbidity of $0.5 \mathrm{McF}$ arland scale tube).

\section{Determination of the Minimum Inhibitory Concentration}

Microplate bioassay was used to determine the Minimum inhibitory concentration - MIC of the assayed phytochemicals. For this was used a microplate with 96 wells (flatted bottom) and cap. The 96-well microplates were prepared dispensing into each well $100 \mu \mathrm{L}$ of doubled strength nutrient broth inoculated with $1 \mathrm{~mL}$ of the bacterium inoculum prior the assay $(1: 9 \mathrm{v} / \mathrm{v}) .100 \mu \mathrm{L}$ of the phytochemical solution with their respective concentration was transferred into seven consecutive wells. Final volume in each well was $200 \mu \mathrm{L}$. The solution having the highest concentration was added into the first well and the lowest concentration was added into the penultimate well. The last well contained $200 \mu \mathrm{L}$ of nutrient broth inoculated with the bacterium inoculum was used as positive control (strain viability). The microplate was asseptically sealed, followed by mixing on plate shaker (300 rpm) for $30 \mathrm{~s}$, and incubated at $28-30{ }^{\circ} \mathrm{C} / 48 \mathrm{~h}$ (Viljoen et al., 2003; Sahin et al., 2004). Antibacterial activity was detected using a colorimetric method by adding $200 \mu \mathrm{L}$ of resauzurin staining (0.1\%) aqueous solution in each well at the end of the incubation period. MIC was defined as the lowest phytochemical concentration able to inhibit the bacteria growth, as 
indicated by resauzurin staining (bacteria died cells are not able to change the staining color by visual observation blue to red) (Palomino et al., 2002; Burt, Reinders, 2003).

\section{Kill time study}

Kill time study was carried out with MIC values previously found in the microplate bioassay. For this was used the viable cells count method. $5 \mathrm{~mL}$ of double strength nutrient broth was inoculated with $1 \mathrm{~mL}$ of the bacterium suspension (approximately $10^{6} \mathrm{cfu} / \mathrm{mL}$ ). After that, $4 \mathrm{~mL}$ of the phytochemical solution, with concentration adjusted to provide a phytochemical final concentration similar to the MIC previously determined, was added to the system and followed by shaking for $30 \mathrm{~s}$ using Vortex. The system was incubated at $37^{\circ} \mathrm{C}$. At different time intervals $(1,2,4,8$, 12 and $24 \mathrm{hs}$ ) of exposure, $1 \mathrm{~mL}$ of the suspension was serially diluted $\left(10^{-1}-10^{-5}\right)$ in sterile peptone water $(0.1 \% \mathrm{w} / \mathrm{v})$ and inoculated on nutrient agar Petri dishes for $24 \mathrm{~h}$ at $37^{\circ} \mathrm{C}$ (Viljoen et al., 2003; Souza et al., 2007). The mean number of colonies ( $\mathrm{cfu} / \mathrm{mL}$ ) was counted and compared with that found in the control assay in which the essential oil solution was replaced by sterile distilled water. The results were expressed in $\log$ of $\mathrm{cfu} / \mathrm{mL}$.

\section{Statistical analysis}

Statistical analysis was performed to determine significant differences $(P<0.05)$ by Tukey test in the bacteria kill time assays. For this was used Sigma stat 2.03 computer program.

\section{RESULTS AND DISCUSSION}

MIC values found for eugenol, $\alpha$-pinene and $\beta$-pinene are shown in Table 1. The assayed phytochemicals presented interesting antimicrobial potential noted by low MIC values. MIC values oscillated between 2.5 (eugenol x $S$. pneumoniae ATCC 11773 ) to $40 \mu \mathrm{L} / \mathrm{mL}$ ( $\beta$-pinene x $S$. epidermidis ATCC 12228). All assayed bacteria strains were sensitive to the phytochemicals. On the other hand, some strains presented resistant behavior to the standard antibiotics, mainly to gentamicin. Eugenol provided the most intense antibacterial effect showing MIC values between 2.5 to $5 \mu \mathrm{L} / \mathrm{mL}$ for the most bacteria strains. S. aureus presented as the most resistant bacterium with MIC values between 10 and $20 \mu \mathrm{L} / \mathrm{mL}$ for the tested phytochemicals. For the other bacteria species were found MIC values oscillating between 2.5 to $5 \mu \mathrm{L} / \mathrm{mL}$ for most interactions.

TABLE I - MIC of some phytochemicals on potential infectious endocarditis causing gram-positive bacteria

\begin{tabular}{|c|c|c|c|c|c|}
\hline \multirow[t]{2}{*}{ Bacteria } & \multicolumn{3}{|c|}{ Phytochemicals $(\mu \mathrm{L} / \mathrm{mL})$} & \multirow{2}{*}{$\begin{array}{l}\text { Penicillin } \\
(10 \mu \mathrm{g} / \mathrm{mL})\end{array}$} & \multirow{2}{*}{$\begin{array}{l}\text { Gentamicin } \\
(10 \mu \mathrm{g} / \mathrm{mL})\end{array}$} \\
\hline & Eugenol & $\beta$-pinene & $\alpha$-pinene & & \\
\hline $\begin{array}{l}\text { S. aureus } \\
\text { ATCC } 13150\end{array}$ & 10 & 20 & 20 & $\mathrm{~S}$ & $\mathrm{R}$ \\
\hline $\begin{array}{l}\text { S. aureus } \\
\text { ATCC } 6538\end{array}$ & 10 & 20 & 20 & $\mathrm{~S}$ & $\mathrm{~S}$ \\
\hline $\begin{array}{l}\text { S. aureus } \\
\text { ATCC } 25923\end{array}$ & 10 & 20 & 20 & $\mathrm{~S}$ & $\mathrm{~S}$ \\
\hline $\begin{array}{l}\text { S. aureus } \\
\text { LB } 126\end{array}$ & 10 & 20 & 10 & $\mathrm{~S}$ & $\mathrm{~S}$ \\
\hline $\begin{array}{l}\text { S. epidermidis } \\
\text { SSI } 1\end{array}$ & 5 & 20 & 5 & $\mathrm{~S}$ & $\mathrm{~S}$ \\
\hline $\begin{array}{l}\text { S. epidermidis } \\
\text { ATCC } 12228\end{array}$ & 5 & 40 & 5 & $\mathrm{~S}$ & $\mathrm{~S}$ \\
\hline $\begin{array}{l}\text { S. pyogenes } \\
\text { ATCC } 19615\end{array}$ & 5 & 20 & 5 & $\mathrm{~S}$ & $\mathrm{R}$ \\
\hline $\begin{array}{l}\text { S. pyogenes } \\
\text { ATCC } 8668\end{array}$ & 5 & 20 & 10 & $\mathrm{~S}$ & $\mathrm{R}$ \\
\hline $\begin{array}{l}\text { S. pneumoniae } \\
\text { ATCC } 11773\end{array}$ & 2.5 & 20 & 5 & $\mathrm{R}$ & $\mathrm{S}$ \\
\hline
\end{tabular}

S: sensitive; R: resistant 
Figure 2, 3 and 4 show the effect of eugenol, $\beta$-pinene and $\alpha$-pinene MIC values on the $S$. aureus ATCC 6538 cell viability. $S$. aureus was chosen to be included in the kill time assays because it is known as the main etiological agent of IE acquired at the community or in nosocomial environment (Niwa et al., 2003; Ishiwada et al., 2005). Phytochemicals MIC values were able to cause a significant $(\mathrm{p}<0.05)$ inhibition of $S$. aureus cell viability providing a bactericidal effect in a maximum time of 24 hours of exposure. Most intense inhibitory effect was showed by $\beta$-pinene and eugenol causing a total elimination of the initial bacterial inoculum after 8 hours of exposure. $\beta$-Pinene and eugenol presented a bacteriostatic effect until 2 hours of exposure and from this time on it was established a progressive decrease in the bacteria cell count. $\alpha$-pinene provided a bacteriostatic effect until 4 hours of exposure being established its cidal effect after 24 hours of exposure.

Some researches have found an antimicrobial effectiveness in phytochemicals, although these data still are considered as incipient when compared to the availability of researches regarding the antimicrobial properties of plant extracts and essential oils (Vasquez et al., 2001; Nostro et al., 2004). Gayoso et al. (2004) and Lima et al. (2005) found antimicrobial effectiveness of pinenes against moulds and pathogen yeasts providing a cidal effect between 2 and 5 hours of exposure. Hao et al. (1998) reported antimicrobial activity of eugenol on Gram positive bacteria, including $S$. aureus strains.

Phytochemicals are small organic biomolecules generally hydrophobic and designated as naturally occurring antibiotics. Cytoplasm membrane coagulation, breakdown of protons motive force, breakdown of electron

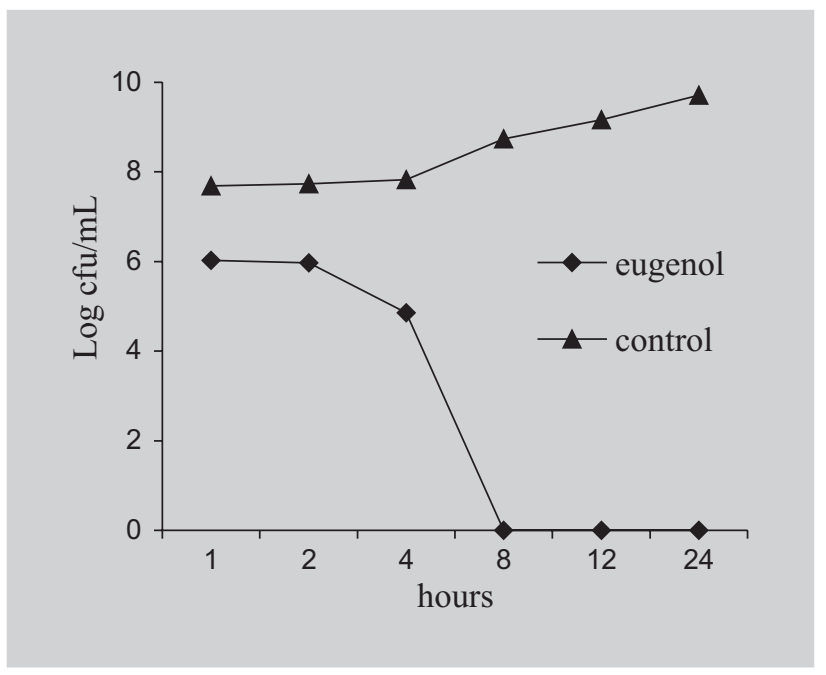

FIGURE 2 - Effect of eugenol $(10 \mu \mathrm{L} / \mathrm{mL})$ on the S. aureus ATCC 6538 viable cells number.

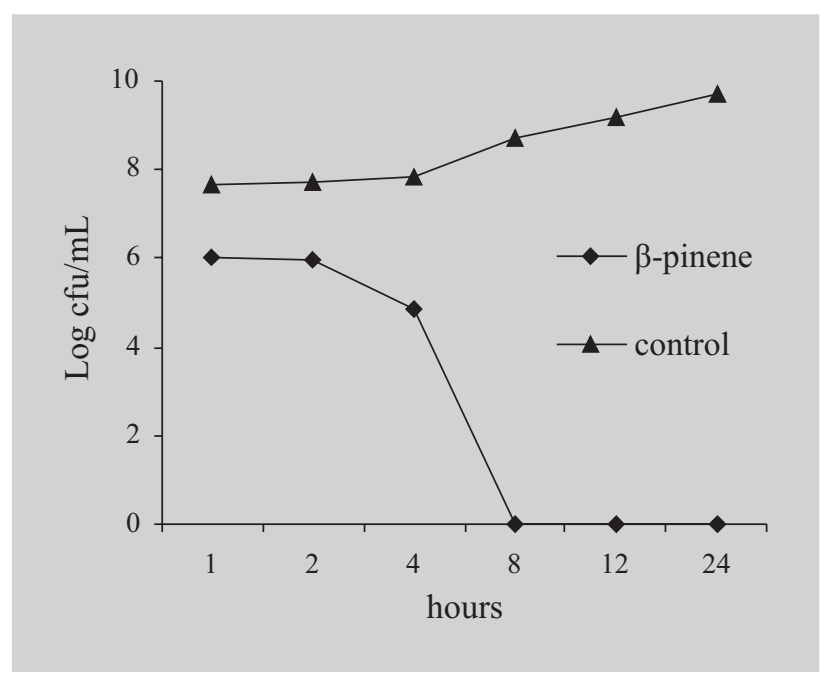

FIGURE 3 - Effect of $\beta$-pinene $(20 \mu \mathrm{L} / \mathrm{mL})$ on the $S$. aureus ATCC 6538 viable cells number.

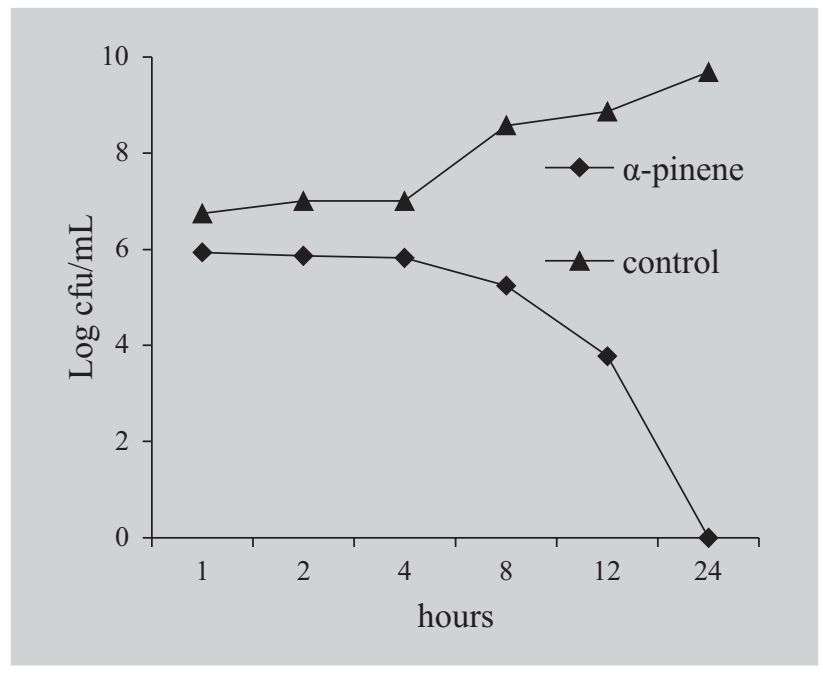

FIGURE 4 - Effect of $\alpha$-pinene $(20 \mu \mathrm{L} / \mathrm{mL})$ on the $S$. aureus ATCC 6538 viable cells number.

flux and active transport unbalance are some events responsible for providing the antimicrobial property of phytochemicals (Sikkema, 1995; Carlson et al., 2002). These biological events have been believed for no occurring separately being some of them activated as consequence of other ones (Sikkema, 1995; Burt, 2004).

Our data show the intense antimicrobial potential of eugenol, $\beta$-pinene and $\alpha$-pinene which were able to inhibit significantly the growth and cell viability of potential infectious endocarditis causing gram-positive bacteria. These results support the recognizing of phytochemicals as alternative antimicrobial compounds to be used in pharmaceutical formulations used in the antibacterial therapy. Further researches are needed to 
evaluate their antimicrobial effectiveness against pathogen microorganisms able to act as etiological agents of different infections diseases, as well as regarding their toxicological and pharmacological aspects.

\section{RESUMO}

Efeito inibitório de eugenol, $\beta$-pineno e $\alpha$-pineno sobre o crescimento de bactérias Gram-positivas potencialmente causadoras de endocardite infecciosa

Este estudo foi conduzido com a proposta de avaliar a efetividade de eugenol, $\beta$-pineno e $\alpha$-pineno em inibir o crescimento de cepas de bactérias Gram-positivas potencialmente causadoras de endocardite infecciosa. A Concentração Inibitória Mínima-CIM dos fitoconstituintes foi determinada através do método de difusão em meio sólido, enquanto a interferência da CIM sobre a viabilidade celular bacteriana foi avaliada através da contagem de células viáveis. Cepas de Staphylococcus aureus, S. epidermidis, Streptococcus pneumoniae $e \mathrm{~S}$. pyogenes $f o-$ ram utilizadas como microrganismos teste nos ensaios antimicrobianos. Os fitoconstituintes ensaiados mostraram efetividade em inibir todas as cepas bacterianas utilizadas como microrganismos testes apresentando valores de CIM entre 2.5 e $40 \mu \mathrm{L} / \mathrm{mL}$. Eugenol apresentou os menores valores de CIM, os quais estiveram entre 2,5 e $5 \mu \mathrm{L} / \mathrm{mL}$ para a maioria das cepas bacterianas. Os valores de CIM encontrados para os fitoconstituintes foram capazes de inibir a viabilidade celular de S. aureus causando uma total eliminação do inóculo bacteriano em um tempo máximo de 24 horas de exposição. Estes dados mostram o intenso potencial antibacteriano dos fitoconstituintes ensaiados e suportam sua possivel e racional aplicação na terapia antimicrobiana.

UNITERMOS: Endocardite. Bactérias Gram-positivas. Fitoconstituintes. Atividade antibacteriana.

\section{REFERENCES}

AKO, J.; IKARI, Y.; HATORI, M. Changing spectrum of infective endocarditis - Review of 194 episodes over 20 years. Circulation, Dallas, v.67, p.3-7, 2003.

ANGUERA, I.; MIRO, J.M.; CABELL, C. H.; ABRUTYN, E. Clinical characteristics and outcome of aortic endocarditis with periannular abscess in the International Collaboration on Endocarditis Merged Database. Am. J. Cardiol., Oxford, vol.96, p.976-981, 2005.
ARAÚJO, J.C.L.V.; LIMA, E.O.; CEBALLOS, B.S.O.; FREIRE, K.R.L.; SOUZA, E.L.; SANTOS FILHO, L. Ação antimicrobiana de óleos essenciais sobre microrganismos potencialmente causadores de infecções oportunistas. Rev. Patol. Trop., Goiás, v.33, p.55-64, 2004.

BADDOUR, L.M.; WILSON, W.R.; BAYER, A.S. Infective endocarditis - Diagnosis, antimicrobial therapy and management of complications. A statement for Healthcare professionals from the commitee on rheumatic fever, endocarditis, and Kawasaki disease, council on cardiovascular disease in the young, and the councils on clinical cardiology, stroke, and cardiovascular surgery and anesthesia, American heart disease. Circulation, Dallas, vol. 14, p.394-434, 2005.

BASHORE, T.M.; CABELL, C.; FOWLER JR, V. Update on infective endocarditis. Cur. Prob. Cardiol., Oxford, v.31, p.274-352, 2006.

BURT, S. Essential oils: their antibacterial properties and potential applications in foods - a review. Int. J. Food Microbiol., Copenhagen, v.94, p.223-253, 2004.

BURT, S.A.; REINDERS, R.D. Antibacterial activity of selected plant essential oils against Escherichia coli O157:H7. Let. Appl. Microbiol., Edinburgh, v.26, p.162167, 2003.

CARLSON, C.F.; MEE, B.J.; RILEY, T.V. Mechanisms of action of Melaleuca alternifolia (tea tree) oil on Staphylococcus aureus determined by time kill, lysis, leakage and salt tolerance assays and electron microscopy. Antimicrob. Agent. Chemother., Chicago, v.46, p.19141920, 2002.

DORMAN, H.J.D.; DEANS, S.G. Antimicrobial agents from plants: antibacterial activity of plant volatile oils. Let. Appl. Bacteriol., Edinburgh, v.88, p.308-316, 2000.

FERREIROS, E.; NACINOVICH, F.; CASABÉ, J.H. Epidemiologic, clinical, and microbiologic profile of infective endocarditis in Argentina: Anational survey. The Endocarditis Infecciosa en la República Argentina - 2 (EIRA-2) Study. Am. Heart J., Durhan, v.151, p.545-552, 2006.

GAYOSO, C.W.; LIMA, E.O.; SOUZA, E.L. Ação inibitória do óleo essencial de Cinnamomum zeylanicum Blume, $\alpha$ pineno e $\beta$-pineno sobre fungos isolados de onicomicoses. J. Bras. Fitomed., São Paulo, v.1, p.25-29, 2004. 
HAO, Y.Y.; BRACKET, R.E.; DOYLE, M.P. Inhibition of Listeria monocytogenes and Aeromonas hydrophila by plant extracts in refrigerated cooked beef. J. Food Prot., Des Moines, v.61, p.307-312, 1998.

ISHIWADA, N.; NIWA, K.; TATENO, S. Causative organism influences clinical profile and outcome of infective endocarditis in pediatric patients and adults with congenital heart disease. Circulation, Dallas, v.69, p.1266-1270, 2005.

LIMA, I.O.; OLIVEIRA, R. A. G.; LIMA, E.O.; SOUZA, E.L.; FARIAS, N.P.; NAVARRO, D.F. Inhibitory action of some phytochemicals on yeasts potentially causing of opportunistic infections. Rev. Bras. Cienc. Farm., São Paulo, v.41, p.199-203, 2005.

NAKATANI, S.; MITSUTAKE, K.; HOZUMI, T. Current characteristics of infective endocarditis in Japan - An analysis of 848 cases in 2000 and 2001. Circulation, Dallas, v.67, p.901-905, 2003.

NASCIMENTO, G.G.F.; LOCATELLI, J.; FREITAS, P.C. Antibacterial activity of extracts and phytochemicals on antibiotic-resistant bacteria. Braz. J. Microbiol., São Paulo, v.31, p.65-72, 2000.

NIWA, K.; NAKAZAWA, M.; MIYATAKE, K. Survey of prophylaxis and management of infective endocarditis in patients with congenital heart disease - Japanese Nationwide survey. Circulation, Dallas, v.67, p.585 591, 2003.

NOSTRO, A.; BLANCO, A.R.; CANNATELLI, M.A.; ENEA, V.; FLAMINI, G.; MORELLI, I.; ROCCARO, A.S.; ALONZO, V. Susceptibility of methicillin-resistant staphylococci to oregano essential oil, carvacrol and thymol. FEMS Microbiol. Let., Oxford, v.230, p.191-195, 2004.

NOTERMANS, S.; HOOGENBOOM-VERDEGAL, A. Existing and emerging foodborne diseases. Int. J. Food Microbiol., Copenhagen, v.15, p.197-305, 1992.

PALOMINO, J.C.; MARTIN, A.; CAMACHO, M.; GUERRA, H.; SWINGS, J.; PORTAELS, F. Resauzurin microtiter assay plate: simple and inexpensive method for detection of drug resistance in Mycobacterium tuberculosis. Antimicrob. Agent. Chemother., Chicago, v.46, p.2720-2722, 2002.
PIGRAU, C.; ALMIRANTE, B.; FLORES, X.. Spontaneous pyogenic vertebral osteomyelitis and endocarditis: Incidence, risk factors, and outcome. Am. J. Med., Chicago, v.118, p.1287-1294, 2005.

SAHIN, F.; GULLUCE, M.; DAFERERA, D.; SOKMEN, A.; POLISSIOU, M.; AGAR, G., OZER, H. Biological activities of the essential oils and methanol extract of Origanum vulgare ssp. vulgare in the Eastern Anatolia region of Turkey. Food Cont., London, v.15, p.549-557, 2004.

SEIDIL, P.R. Pharmaceuticals from natural products: current trends. An. Acad. Bras. Cien., São Paulo, v.74, p.145-150, 2000 .

SIKKEMA, J.; DE BONTE, J.A.M.; POOLMAN, B. Mechanisms of membrane toxicity of hydrocarbons. Microbiol. Rev., Oxford, v.59, p. 201-222, 1995.

SOUZA, E.L.; LIMA, E.O.; FREIRE, K.R.L.; SOUSA, C.P. Inhibitory action of some essential oils and phytochemicals on the growth of moulds isolated from foods. Braz. Arch. Biol. Technol., Curitiba, v.2, p.245-250, 2005.

SOUZA, E.L.; STAMFORD, T.L.M.; LIMA, E.O.; TRAJANO, V.N. Effectiveness of Origanum vulgare L. essential oil to inhibit the growth of food spoiling yeasts. Food Control, v.19, p.408-413, 2007.

VASQUEZ, B.I.; FENTE, C.; FRANCO, C.M.; VASQUEZ, M.J.; CEPEDA, A. Inhibitory effects of eugenol and thymol on Penicillium citrium strains in culture media and cheese. Int. J. Food Microbiol., Copenhagen, v.67, p.157163, 2001.

VILJOEN, A.; VAN VUUREN, S.; ERNST, E.; KLEPSER, M.; DEMIRCI, B.; BASER, H.; VAN WYK, B.E. Osmitopsis astericoides (Asteraceae) - the antimicrobial activity and essential oil composition of a Cape-Dutch remedy. J. Ethnopharmacol., Leinden, v.88, p.137-143, 2003.

WATANABE, Y.; TAKETANI, Y.; TAKEI, Y. Complete heart block resulting from quadricuspid aortic valve penicillinresistant pneumococcal endocarditis - a case report. Circulation, Dallas, v.67, p.285-276, 2003.

Recebido para publicação em 09 de agosto de 2006. Aceito para publicação em 28 de fevereiro de 2007. 